I $\mathbf{J}$

Home Science Extension And Communication Management

Volume 2 | Issue 1 | Jan., 2015 | 71-73
- DOI : 10.15740/HAS/IJHSECM/2.1/71-73

- Visit us : www.researchjournal.co.in

\title{
Effect of media on youth crime
}

\section{SHALINI GUPTA*, MITHILESH VERMA AND ANAMIKA SINGH}

Department of Extension Education and Communication Management, College of Home Science, Chandra Shekhar Azad University of Agriculture and Technology, KANPUR (U.P.) INDIA

\begin{abstract}
The study entitled, "Effect of media on youth crime" was carried in district Kanpur and Lucknow in the year 2014 to assess the Youth opinion and views about role of media to present the youth crime. Thus, 2 different colleges and 2 different universities were selected from both Lucknow and Kanpur districts with 160 respondents. 50 per cent male respondents with mean age 20 years and standard deviation is 2 year and 50 per cent female respondents with mean age 21 years and standard deviation is 2 year. 45.6 per cent male respondent have understand that youth crime really on the rice in recent time with mean score of 1.91 and given rank 1 whereas 45.0 per cent of female respondent have understand that media aware and increase the knowledge of youth in recent years with mean score 1.90 and given rank I.
\end{abstract}

KeY Words : Effect, Media, Youth Crime

View Point Article : Gupta, Shalini, Verma, Mithilesh and Singh, Anamika (2015). Effect of media on youth crime. Internat. J. Home Sci. Extn. \& Comm. Manage., 2 (1): 71-73.

Article History : Received : 29.11.2014; Accepted : 28.12.2014

\footnotetext{
* Author for correspondence
} 